\title{
Long-term outcomes of tissue-based ACTH-antibody assay-guided transsphenoidal resection of pituitary adenomas in Cushing disease
}

\author{
J. Mark Erfe, MPH, ${ }^{1}$ Avital Perry, MD, ${ }^{2}$ John McClaskey, MD, ${ }^{3}$ Silvio E. Inzucchi, MD, ${ }^{4}$ \\ Whitney Sheen James, MD, MHS, ${ }^{5}$ Tore Eid, MD, PhD, ${ }^{6}$ Richard A. Bronen, MD, \\ Amit Mahajan, MD, ${ }^{7}$ Anita Huttner, MD, ${ }^{8}$ Florecita Santos, MT, ${ }^{6}$ and Dennis Spencer, MD ${ }^{9}$ \\ Sections of ${ }^{4}$ Endocrinology, ${ }^{6}$ Laboratory Medicine, and ${ }^{7}$ Radiology and Biomedical Imaging; Departments of ${ }^{8}$ Pathology and \\ ${ }^{9}$ Neurological Surgery, ${ }^{1}$ Yale School of Medicine, New Haven, Connecticut; ' ${ }^{2}$ epartment of Neurological Surgery, Mayo Clinic, \\ Rochester, Minnesota; ${ }^{3}$ Department of Pathology, Mount Sinai Hospital, New York, New York; and 5ivision of Neurosurgery, \\ University of Arizona, Tucson, Arizona
}

OBJECTIVE Cushing disease is caused by a pituitary micro- or macroadenoma that hypersecretes adrenocorticotropic hormone (ACTH), resulting in hypercortisolemia. For decades, transsphenoidal resection (TSR) has been an efficacious treatment but with certain limitations, namely precise tumor localization and complete excision. The authors evaluated the novel use of a double-antibody sandwich assay for the real-time quantitation of ACTH in resected pituitary specimens with the goals of augmenting pathological diagnosis and ultimately improving long-term patient outcome.

METHODS This study involved a retrospective review of records and an analysis of assay values, pathology slides, and MRI studies of patients with Cushing disease who had undergone TSR in the period from 2009 to 2014 and had at least 1 year of follow-up in coordination with an endocrinologist. In the operating room, biopsy specimens from the patients had been analyzed for tissue ACTH concentration. Additional samples were simultaneously sent for frozen-section pathological analysis. The ACTH assay performance was compared against pathology assessments of surgical tumor samples using receiver operating characteristic (ROC) analysis and against pre- and postoperative MRI studies.

RESULTS Fourteen patients underwent TSR with guidance by ACTH-antibody assay and pathological assessment of 127 biopsy samples and were followed up for an average of 3 years. The ACTH threshold for discriminating adenomatous from normal tissue was $290,000 \mathrm{pg} / \mathrm{mg}$ of tissue, based on jointly maximized sensitivity (95.0\%) and specificity $(71.3 \%)$. Lateralization discordance between preoperative MRI studies and surgical visualization was noted in 3 patients, confirming the impression that MRI alone may not achieve optimal localization. A majority of the patients (85.7\%) attained long-term disease remission based on urinary free cortisol levels, plasma cortisol levels, and long-term corticosteroid therapy. Comparisons of patient-months of remission and treatment failure showed that the remission rate in the study sample statistically exceeds the rate in historical controls $(71.9 \% ; p=0.0007$, Fisher's exact test). Long-term unexpected hormonal deficiencies were statistically similar between study patients (29\%) and those in a meta-analysis (25\%; $p=0.7596$, Fisher's exact test).

CONCLUSIONS These preliminary findings reflect the promising potential of tissue-based ACTH-antibody-guided assay for improving the cure rates of Cushing disease patients undergoing TSR. Further studies with larger sample sizes, further refinements of assay interpretation, and longer-term follow-ups are needed.

https://thejns.org/doi/abs/10.3171/2017.3.JNS162245

KEY WORDS transsphenoidal resection; Cushing disease; ACTH; pituitary adenoma; pituitary surgery 


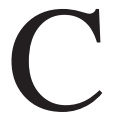
USHING disease is the most frequent cause of endogenous hypercortisolism, also known as "Cushing syndrome." 56,69 The high morbidity and mortality of the disease, along with its protean manifestations, put a premium on accurate and timely diagnosis and treatment. Remission rates following transsphenoidal resection (TSR) in patients with Cushing disease are cited at $70 \%-90 \% .^{10,15,19,25,29,32,45,55,59,61-63}$ Higher-than-expected recurrence rates are often attributed to incomplete resection. Postoperative recurrence mainly occurs at the tumor margin, making the intraoperative distinction between normal and pathological tissue critical. Precise tumor localization is necessary for maximizing the probability of remission while minimizing the risk of postoperative hypopituitarism. Current protocols largely rely on pathological assessments of frozen sections, and there have been many attempts to increase the precision of tumor margin determination.

Transsphenoidal pituitary surgery is the preferred treatment for Cushing disease because it is most likely to result in sustained remission along with preservation of normal pituitary function. ${ }^{7}$ Systematic microsurgical exploration of the sella turcica is often guided by preoperative MRI or by lateralization assessment from bilateral inferior petrosal sinus sampling (BIPSS), both of which suffer from suboptimal sensitivity and thus allow for incomplete resections especially if pathological frozen sections fail to identify tumor. ${ }^{43,44}$ For instance, MRI detects only about $50 \%$ of Cushing adenomas, and gadolinium contrast and 3D gradient echo acquisition can increase false positives. ${ }^{24,46,66}$ Bilateral inferior petrosal sinus sampling has been associated with false negatives because of improper catheter placement, anomalous venous drainage, and generally low to moderate sensitivity $(59 \%-71 \%) .{ }^{35,44,64,65}$ Better diagnostic and tumor localization techniques are needed to increase the likelihood that initial resections are curative.

The goal of the present study was to use a newly developed intraoperative assay to help guide surgery for Cushing disease. Intraoperative assays of plasma hormone levels have been used in other disorders to improve outcomes, for example, in the resection of parathyroid tissue for hyperparathyroidism. ${ }^{6,13,41}$ Similarly, different methods of intraoperative adrenocorticotropic hormone (ACTH) measurements have been examined with the goal of minimizing unnecessary hypophysectomies and maximizing remission rates in patients with Cushing, using radioimmunoassays, ACTH venous plasma levels, or ultrasoundhomogenized adenoma ACTH measurements. ${ }^{16,36,51}$ However, these previous methods were not successful. In this paper we report the novel use at Yale New Haven Hospital (YNHH), Department of Laboratory Medicine, of a sandwich ACTH-antibody assay (Elecsys) for guiding tumor localization during TSR. In contrast to older assays for intraoperative ACTH measurement, the sandwich assay significantly reduces the sample preparation and processing time by eliminating the need for sample preincubation. Additionally, the assay's safety profile has been improved because neither the antigen detection nor the antibody measurement steps require radioactivity or ultrasound homogenization.

\section{Methods}

\section{Sample Collection and Preparation}

For each patient, MRI-identified areas suspicious for an adenoma were biopsied and processed intraoperatively for ACTH levels and as frozen sections for pathological evaluation. Subsequent biopsies were used to confirm neoplasmfree margins, especially if the tumor was not a discrete, easily dissectible nodule. If a tumor had not been definitely seen on preoperative MRI, the dura mater was opened widely and the gland explored. A vertical incision was made in the gland on the side with higher BIPSS ACTH values and situated as if the gland were to be divided into thirds. Each third was sampled anteriorly to posteriorly, and the extent of resection was based on ACTH levels, which usually agreed with the pathological diagnosis of tumor. Before ACTH levels were available, if a tumor was not identified pathologically after two-thirds of the gland had been removed, the residual gland either remained unresected or, in some circumstances, was subjected to a total hypophysectomy. In this latter group, resection was guided by any positive indicator of tumor, and if pathology was negative, elevated ACTH levels were used.

As noted above, both ACTH measurements and pathology were analyzed in the same biopsied tissue fragment. The neurosurgeon sketched a diagram of the pituitary on sterilized paper, and each biopsied fragment was given a number and location (for example, left anterior inferior) as illustrated in Fig. 1. Each tissue sample was placed on a piece of Telfa by the neurosurgeon, handed over to the technologist with the number and source of the sample, weighed on an analytical pan balance with a mass resolution of $0.1 \mathrm{mg}$, and transferred to a lysing matrix tube. Tare weight was subtracted from gross weight for all tube samples.

Tissue specimens were subsequently homogenized for 2 minutes by rapid multidirectional agitation with specialized lysing matrix beads in $1 \mathrm{ml}$ of lysis buffer using a FastPrep-24 homogenizer (MP Biomedicals, LLC) at a spin setting of 6 for 45 seconds. Homogenized specimens were then processed in an Eppendorf Quick-Pak microcentrifuge for 1 minute. Multiple dilutions were conducted in parallel in $0.15 \mathrm{M} \mathrm{NaCl}$ at factors of 1:100, 1:1000, and 1:5000. Most specimens required dilutions up to 5000fold to lower the ACTH concentration into the analytical measurement range and to avoid high-dose "hook effects." Such an effect was not observed in the assay results below ACTH concentrations of $10^{6} \mathrm{pg} / \mathrm{ml}$. The total duration of assay processing (first 2 steps described above) on the Roche cobas e411 immunoassay analyzer, using the Elecsys ACTH reagent kit, was 18 minutes.

\section{ACTH-Antibody Assay}

The Elecsys ACTH assay employs a sandwich test principle with 2 monoclonal antibodies specific for the N-terminal region (aa 9-12) and for the C-terminal region (aa 36-39). Active ACTH shares these epitopes with its precursors, pro-ACTH and pro-opiomelanocortin (POMC), enabling antibody recognition of all 3 antigenic structures. Sample volumes must be at least $100 \mu \mathrm{l}$, and the assay has a detection limit of $1.00 \mathrm{pg} / \mathrm{ml}$. The first step (9 min- 


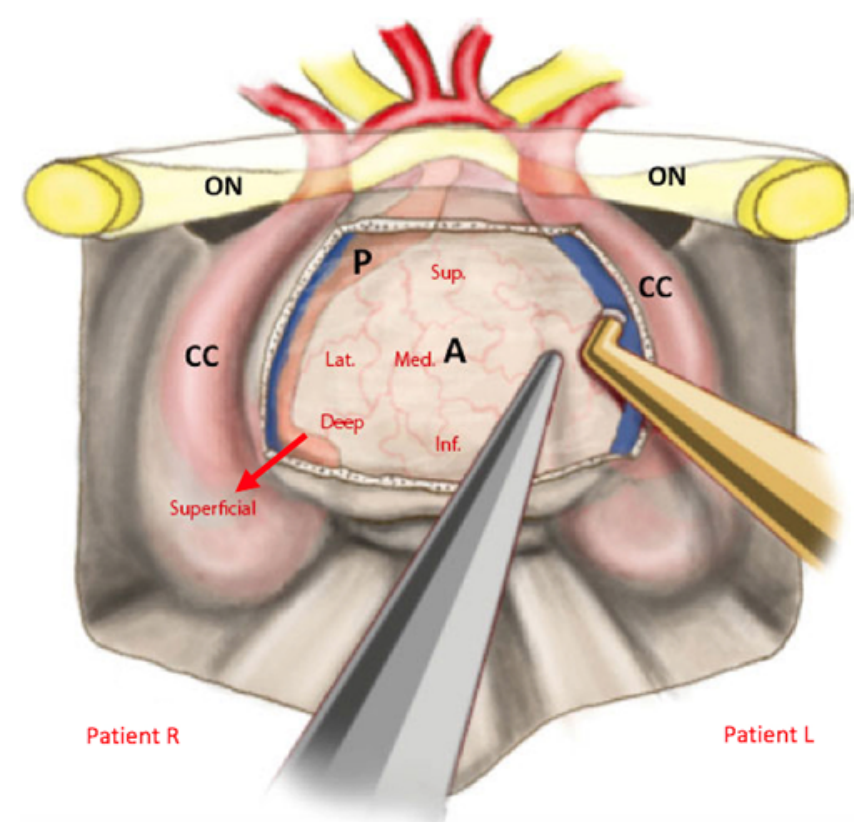

FIG. 1. Sample orientation was recorded in 3D space along 3 axes and labeled right (Patient $\mathrm{R}$ ) or left (Patient $\mathrm{L}$ ): superior (Sup.) to inferior (Inf.), lateral (Lat.) to medial (Med.), and deep to superficial. $A=$ adenoma; $\mathrm{CC}=$ cavernous carotid arteries; $\mathrm{ON}=$ optic nerve; $\mathrm{P}=$ pituitary gland. Figure modified with permission from Daniel F. Kelly Neurosurgical Inc., from Kelly DF, et al: A Patient's Guide to Endonasal Endoscopic Surgery for Pituitary Adenomas and Related Tumors. Pacific Pituitary Center at Providence Saint John's Health Center, 2015. Figure is available in color online only.

utes) involves sample incubation with both a biotinylated monoclonal ACTH-specific antibody and a ruthenylated monoclonal ACTH-specific antibody to form a sandwich complex. In the second step (9 minutes), streptavidin-coated magnetic microparticles are added to the reaction and the immune complex binds to the solid phase via biotinstreptavidin interactions. The third and final step involves transferring the microparticles to a measuring cell where they can be captured magnetically by an electrode surface. Unbound sample is washed away before a voltage is applied to the electrode, triggering a chemiluminescent reaction that can be measured by a photomultiplier to determine the ACTH concentration of the sample.

Biopsy specimens obtained from patients undergoing TSR were analyzed in real time in the operating room for tissue ACTH concentration. The tissues from tumor margins as well as obvious tumor were simultaneously submitted for frozen-section pathological analysis and intraoperative ACTH measurement. An ACTH level of 200,000 $\mathrm{pg} / \mathrm{mg}$ in tumor tissue was chosen using estimates based on manufacturer-reported assay characteristics, iterative sample testing and analysis of control patients, and the literature. Flitsch et al. showed that among 31 single samples of adenomatous and normal brain tissue, the minimum ACTH level was $345,000 \mathrm{pg} / \mathrm{mg}$ of tissue. ${ }^{22}$ Our initial ACTH sampling was used to identify the tissues as positive or negative for tumor using a lower $200,000-\mathrm{pg} / \mathrm{mg}$ threshold to achieve a higher likelihood of complete tumor resection while minimizing the risk of erroneous detec- tion of uncleaved POMC in normal tissue. Assay samples were compared with both the frozen-section analysis and the permanent pathological diagnosis. Finally, the first and senior authors examined each frozen section with the neuropathologist, compared the pathological findings with the $\mathrm{ACTH}$ measurements, and examined the subsequent control of each patient's ACTH as well as the postoperative endocrine outcome, based on a retrospective chart review.

\section{Retrospective Records Analysis}

This study involved a retrospective records review and analysis of assay values, pathology slides, and MRI studies of patients with Cushing disease. All study procedures were conducted in accordance with forms approved by the institutional Human Investigation Committee of Yale School of Medicine. The list of potential study subjects consisted of patients with Cushing disease who had undergone, for the first time, a TSR performed by a single neurosurgeon (senior author) in the period from 2009 to 2014. The diagnosis of Cushing disease was established on the basis of clinical presentation and endocrine evaluations including urine, serum, and salivary cortisol, dexamethasone suppression testing, and, when indicated, corticotropin-releasing hormone stimulation and BIPSS. All study subjects had at least 1 year of follow-up in coordination with an endocrinologist. Follow-up was defined as the period in months from the date of TSR until the most recent neurosurgical or endocrine follow-up appointment.

Postoperative serum cortisol levels that are predictive of cure in the literature range from 2 to $3 \mu \mathrm{g} / \mathrm{dl}$, with lower levels associated with a greater chance of hypopituitarism. ${ }^{15,28,45}$ While it is useful to predict the probability of cure based on postoperative serum cortisol, long-term remission is best measured during follow-up and is based on urinary free cortisol (UFC). At a maximum diagnostic threshold of $180 \mathrm{nmol}$ per 24 hours, reported sensitivity and specificity of UFC in detecting cortisol excess are 94\%-95\% and 94\%-98\%, respectively, and exceed those of other measurements. ${ }^{17,27,30}$ Urinary free cortisol measurements less than $50 \mu \mathrm{g}$ or approximately $137 \mathrm{nmol}$ per 24 hours are normal using the YNHH test. Cure status was based on whether long-term UFC measurements were normal, and if those data were not available, then a combination of postoperative plasma cortisol and the need for long-term corticosteroid replacement was used.

We gathered patient demographic data pertaining to age, sex, height, and weight, as well as treatment and outcome variables. The pre- and postoperative cortisol levels, reported as either 24-hour UFC or morning fasting plasma lab values, were examined to establish whether the disease was cured (confirmed by cortisol values in the normal or below-normal ranges). Unexpected postoperative hormonal changes were also taken from neurosurgical notes and progress reports from patient encounters to establish the degree to which each patient suffered from hypopituitarism, hypothyroidism, postoperative CSF leakage, diabetes insipidus, hypogonadism, and optic chiasmal injury. Additional treatment variables were also examined, including whether the patient underwent multiple TSRs and whether the patient underwent postsurgical bilateral adrenalectomy or postsurgical stereotactic radiosurgery. 
Commentaries from the pathological record were included for each examined biopsy. Samples were coded as positive if the commentary included unambiguous reference to tumor characteristics or an adenomatous state. Intraoperative assay values were acquired for each biopsy from patient records kept in the Department of Laboratory Medicine of $\mathrm{YNHH}$.

\section{Statistical Evaluation of ACTH Assay}

Assay evaluation was conducted in two parts. The first part involved tabulating and evaluating the available assay values using receiver operating characteristic (ROC) analysis with pathological frozen sections serving as the standard against which assay performance was compared. Our rationale for this approach is the common use of pathological assessment of frozen tissue slices as the functional standard for adenoma margin discrimination in the operating room. The second part of the assay evaluation explored this assumption by comparing the performance of both the ACTH assay and the pathological assessment in terms of long-term patient outcomes.

We included in the ROC analysis only those patient biopsies for which both pathological assessment and intraoperative ACTH values were available. A sample size calculation was performed in MedCalc 15.4 to validate the study sample size, which was based on total biopsy samples, treated as independent tests of the ACTH assay versus the pathological assessment. The ROC curve was generated using Stata version 13 (StataCorp LP). Sensitivity, specificity, and concordance calculations between the assay and pathological assessment were conducted in Microsoft Excel 2013.

\section{MRI Assessment}

Preoperative and postoperative MRI of the pituitary gland was performed on either 1.5- or 3-T imaging systems. Multiple sequences were obtained through the sella, including high-resolution coronal T1-weighted, coronal T2-weighted, and sagittal T1-weighted images followed by postcontrast dynamic coronal and static sagittal and coronal high-resolution T1-weighted images. Two neuroradiologists (A.M. and R.A.B.) evaluated the MRI studies, utilizing a consensus opinion to determine a focal abnormality or region of relative poor enhancement. Sizes of 1) adenomatous lesions and 2) pituitary glands inclusive of the lesion were determined along 3 axes: transverse (TR), craniocaudal (CC), and anteroposterior (AP). Total volumes were calculated using ellipsoid assumptions according to the equation $(4 / 3)(\pi)(\mathrm{TR})(\mathrm{CC})(\mathrm{AP})$. Tumors were judged to be discrete based on whether they had welldefined borders and were easily seen by both radiologists. Correlation with ACTH assay was performed to assess for concordance/discordance. Postoperative MR images were evaluated to assess for completeness of resection and evidence of residual gland.

\section{Results \\ Demographics and Treatment Data}

Fourteen patients $\left(\mathrm{n}_{1}\right)$ fit the inclusion criteria outlined in Methods. Four subjects were male, and 10 were female.
The average age was $48.3 \pm 13.5$ years (range $24-69$ years). Average body mass index was $32.3 \pm 7.8 \mathrm{~kg} / \mathrm{m}^{2}$. All patients underwent dexamethasone suppression testing, and 7 patients (Cases 1, 2, 5, 6, 8, 9, 14) required BIPSS during their diagnostic workups. All patients underwent TSR for the first time.

Table 1 provides relevant surgical and follow-up data for all 14 subjects. All patients had at least 12 months of follow-up by the completion of the study, with an average follow-up time of about 2 years 9 months (33.4 months). Within 3-5 days of surgery, the plasma cortisol levels averaged $3.4 \mu \mathrm{g} / \mathrm{dl}$ (SD $2.9 \mu \mathrm{g} / \mathrm{dl})$. Eleven $(78 \%)$ of the 14 patients reported levels lower than $5 \mu \mathrm{g} / \mathrm{dl}$.

Long-term endocrinological follow-up provided 24hour UFC levels for 12 of the 14 patients. The UFC levels for Cases 7 and 12 were not measured postoperatively, but other low cortisol measures confirmed cure status. Case 7 had an immediate postoperative cortisol value of $0.7 \mu \mathrm{g} /$ dl. Case 12 had a long-term morning plasma cortisol of $0.4 \mu \mathrm{g} / \mathrm{dl}$, which was below the lower limit of the normal range. Twelve of the 14 patients attained definitive longterm cure. The UFC levels failed to normalize in 1 patient, and another patient continues to be evaluated.

The patients in Cases 10 and 14 have not definitively reached long-term remission. Pathology and intraoperative ACTH levels for the patient in Case 10 confirmed a pituitary adenoma in 1 of her 4 biopsies. However, MRI changes in the year following surgery showed nonspecific residual enhancement, and long-term UFC has continued to uptrend. She is currently receiving Gamma Knife radiation. In Case 14 preoperative MRI had been interpreted as showing a posterior adenoma, which appeared resected on postoperative imaging. The patient had 22 intraoperative biopsies. His data were discordant, with only one fragment suggestive of adenoma but not definitive; however, many of the samples in the MRI-positive region had very high ACTH levels, some more than 1 million units. This patient's immediate postoperative plasma cortisol was 6.7 $\mu \mathrm{g} / \mathrm{dl}$, but his postoperative ACTH was $<5 \mathrm{ng} / \mathrm{L}$, consistent with complete adenoma removal. ${ }^{23}$ His long-term UFC was $72 \mu \mathrm{g} / 24 \mathrm{hrs}$, which exceeded the normal range of $50 \mu \mathrm{g} / 24 \mathrm{hrs}$, but he is unable to wean himself from long-term prednisone as cortisol replacement because of postwithdrawal hypotension following multiple withdrawal attempts. Additionally, his long-term UFC may reflect prednisone intake and should be interpreted with caution. Notably, his recent ACTH level of 16 reflects a normalrange hypothalamus-pituitary response. It is unclear at this time whether he is cured.

\section{ROC Analysis for Optimizing Assay Threshold}

The minimum ROC sample size was calculated in accordance with the methodology for ROC analysis outlined in Hanley and McNeil. ${ }^{26}$ With the constraints that Type I and II errors not respectively exceed $5 \%$ and $20 \%$, that the area under the ROC curve be at least $80 \%$, that the null hypothesis be equivalent to 0.50 , and that the ratio of sample sizes in the negative and positive groups be approximately one-to-one, a total of 26 cases -13 positive and 13 negative-are required. The acquired sample $\left(\mathrm{n}_{2}=\right.$ 127 biopsy samples) meets this criterion. The ROC curve 
TABLE 1. Summary of demographic and lab data in 14 patients with Cushing disease treated with TSR

\begin{tabular}{|c|c|c|c|c|c|c|c|c|c|}
\hline Parameter & Sex & $\begin{array}{l}\text { Surgery } \\
\text { Date }\end{array}$ & $\begin{array}{l}\text { Age } \\
\text { (yrs) }\end{array}$ & $\begin{array}{c}\mathrm{FU} \\
(\mathrm{mos})\end{array}$ & $\begin{array}{l}\text { Preop UFC Cortisol } \\
(\mu \mathrm{g} / 24 \mathrm{hrs})\end{array}$ & $\begin{array}{l}\text { Immediate Postop } \\
\text { Serum Cortisol }(\mu \mathrm{g} / \mathrm{dl})\end{array}$ & $\begin{array}{l}\text { Long-term Postop UFC } \\
\text { Cortisol ( } \mu \mathrm{g} / 24 \mathrm{hrs})\end{array}$ & $\begin{array}{c}\% \text { UFC } \\
\text { Decrease }\end{array}$ & $\begin{array}{l}\text { Cure } \\
\text { Status }\end{array}$ \\
\hline \multicolumn{10}{|l|}{ Case No. } \\
\hline 1 & $\mathrm{~F}$ & 2009 & 68 & 64 & 112 & 1 & 33 & 70.5 & Yes \\
\hline 2 & $M$ & 2009 & 47 & 56 & 489 & 3 & 4 & 99.2 & Yes \\
\hline 3 & $\mathrm{~F}$ & 2009 & 43 & 70 & 67 & 9 & 24 & 64.2 & Yes \\
\hline 4 & $\mathrm{~F}$ & 2009 & 49 & 43 & 217 & 1 & 16 & 92.6 & Yes \\
\hline 5 & $\mathrm{~F}$ & 2009 & 62 & 42 & 147 & 2 & 10 & 93.2 & Yes \\
\hline 6 & $\mathrm{~F}$ & 2009 & 53 & 40 & 121 & 1 & 40 & 66.9 & Yes \\
\hline 7 & $\mathrm{~F}$ & 2011 & 48 & 12 & 121 & 1 & NM & NA & Yes \\
\hline 8 & $M$ & 2011 & 24 & 12 & 466 & 3 & 27 & 94.2 & Yes \\
\hline 9 & $\mathrm{~F}$ & 2011 & 48 & 25 & 242 & 2 & 18 & 92.6 & Yes \\
\hline 10 & $\mathrm{~F}$ & 2012 & 47 & 36 & 503 & 3 & 64 & 87.3 & No \\
\hline 11 & $\mathrm{~F}$ & 2012 & 29 & 27 & 85 & 9 & 35 & 58.8 & Yes \\
\hline 12 & $\mathrm{~F}$ & 2013 & 69 & 16 & 161 & 1 & NM & NA & Yes \\
\hline 13 & $M$ & 2014 & 32 & 12 & 161 & 4 & 1 & 99.4 & Yes \\
\hline 14 & $M$ & 2014 & 57 & 12 & 161 & 7 & 72 & 55.3 & No \\
\hline Mean & & & 48.3 & 33.4 & 218.1 & 3.4 & 28.7 & 81.2 & \\
\hline SD & & & 13.5 & 20.1 & 152.4 & 2.9 & 22.0 & 16.6 & \\
\hline
\end{tabular}

$\mathrm{FU}=$ follow-up; $\mathrm{NA}=$ not available; $\mathrm{NM}=$ not measured; $\mathrm{SD}=$ standard deviation .

for the ACTH assay values compared against pathological assessments of biopsies is plotted in Fig. 2. The area under the curve (AUC) measures 0.8552, which indicates that the assay conforms very well to the pathological assessments, relative to random chance $(y=x)$.

Assay thresholds were evaluated from 100,000 to $350,000 \mathrm{pg} / \mathrm{mg}$ of tissue, and their associated test performance characteristics were calculated (Table 2). Above each threshold, assay values were considered positive for tumor. Concordant pairs are biopsies for which the assay and the assessment agreed, and discordant pairs are biopsies for which they disagreed. In the ROC analysis, maximizing the sensitivity (true-positive rate) while minimizing (1 - specificity) (false-positive rate) is the ideal threshold. Applying this approach yields an optimal threshold of about $290,000 \mathrm{pg} / \mathrm{mg}$ of tissue. At this threshold, the falsepositive rate $(28.7 \%)$ is kept near its lowest value $(27.6 \%)$ in this ACTH range while maintaining sensitivity $(95.0 \%)$ close to its highest value $(97.5 \%)$ in this ACTH range. The universe of all possible strategies can be thought of as existing along a threshold-dependent continuum, with more "aggressive" strategies requiring lower thresholds (northeast quadrant of Fig. 2) and more "conservative" approaches depending on higher thresholds (southwest quadrant of Fig. 2).

\section{Concordance of Pathological Sections With ACTH Assay for an Empirical Threshold of $200,000 \mathrm{pg} / \mathrm{mg}$ of Tissue}

The operating protocol at $\mathrm{YNHH}$ utilizes a relatively lower threshold of 200,000 pg/mg of tissue. During TSR, samples were assessed by both pathology and ACTH assay, and if either of these tests came back positive for tumor, then resection continued. In this section of the paper, we report on the outcomes of 14 patients $\left(n_{1}\right)$ who received this more aggressive surgical regimen.

A total of 127 biopsy samples $\left(n_{2}\right)$ from the 14 subjects had both an intraoperative ACTH assay value and pathological assessment. Samples were treated as independent since categorical determinations of the presence or ab-

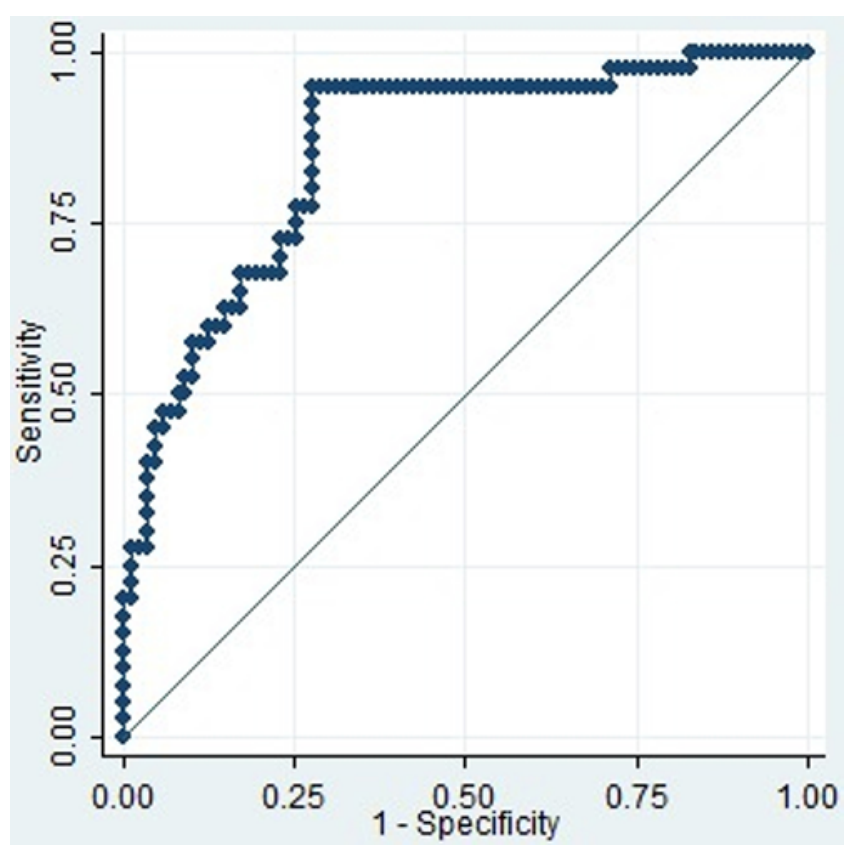

FIG. 2. Area under the ROC curve $=0.8552$. Figure is available in color online only. 
TABLE 2. ROC criterion analysis of 127 biopsy samples

\begin{tabular}{|c|c|c|c|c|c|c|c|c|c|}
\hline $\begin{array}{l}\text { Criterion } \\
\text { (pg/mg) }\end{array}$ & $\begin{array}{c}\text { Assay Positive } \\
\text { (no.) }\end{array}$ & $\begin{array}{l}\text { Assay Negative } \\
\text { (no.) }\end{array}$ & $\begin{array}{c}\text { Assay Positive } \\
(\%)\end{array}$ & $\begin{array}{l}\text { Concordant Pairs } \\
\text { (no.) }\end{array}$ & $\begin{array}{l}\text { Discordant Pairs } \\
\text { (no.) }\end{array}$ & $\begin{array}{c}\text { Sensitivity } \\
(\%)\end{array}$ & $\begin{array}{c}1 \text { - Specificity } \\
(\%)\end{array}$ & $\begin{array}{l}\text { PPV } \\
(\%)\end{array}$ & $\begin{array}{l}\text { NPV } \\
(\%)\end{array}$ \\
\hline 100,000 & 101 & 26 & 79.5 & 64 & 63 & 97.5 & 71.3 & 38.6 & 96.2 \\
\hline 150,000 & 86 & 41 & 67.7 & 77 & 50 & 95.0 & 55.2 & 44.2 & 95.1 \\
\hline 200,000 & 77 & 50 & 60.6 & 86 & 41 & 95.0 & 44.8 & 49.4 & 96.0 \\
\hline 250,000 & 70 & 57 & 55.1 & 93 & 34 & 95.0 & 36.8 & 54.3 & 96.5 \\
\hline 260,000 & 68 & 59 & 53.5 & 95 & 32 & 95.0 & 34.5 & 55.9 & 96.6 \\
\hline 270,000 & 65 & 62 & 51.2 & 98 & 29 & 95.0 & 31.0 & 58.5 & 96.8 \\
\hline 280,000 & 64 & 63 & 50.4 & 99 & 28 & 95.0 & 29.9 & 59.4 & 96.8 \\
\hline 290,000 & 63 & 64 & 49.6 & 100 & 27 & 95.0 & 28.7 & 60.3 & 96.9 \\
\hline 300,000 & 61 & 66 & 48.0 & 100 & 27 & 92.5 & 27.6 & 60.7 & 95.5 \\
\hline 350,000 & 55 & 72 & 43.3 & 94 & 33 & 77.5 & 27.6 & 56.4 & 87.5 \\
\hline
\end{tabular}

Concordant pairs are biopsy samples for which the assay and the assessment agreed; discordant pairs are biopsy samples for which they disagreed. Boldface type signifies the threshold used at YNHH $(200,000 \mathrm{pg} / \mathrm{mg})$ and the optimal threshold $(290,000 \mathrm{pg} / \mathrm{mg})$.

sence of adenomatous tissue or an ACTH level beyond $200,000 \mathrm{pg} / \mathrm{mg}$ of tissue for each biopsy sample did not depend on the values for other biopsy samples in the study. Table 3 shows the $2 \times 2$ contingency table for the assay versus pathological assessment. A total of 86 samples were concordant across both tests, and 41 were discordant.

The calculated evaluative measures (Table 4) characterize assay performance against pathological assessment. The low number of false negatives imparts a high degree of sensitivity and negative predictive value (NPV) to the assay (95.0\% and $96.0 \%$, respectively), but the high number of false positives renders the assay less appropriate for distinguishing borderline tumor or ambiguous tissue. This is reflected in the low specificity of the assay (55.2\%) and the low positive predictive value (PPV) (49.4\%). Furthermore, the kappa measure of agreement $(\kappa=0.41)$ indicates that there is substantial disagreement between the ACTH assay and pathological assessment.

It is instructive to closely inspect the circumstances of biopsies for which assay and pathological assessment were discordant, due to either 1) negative assay and positive pathology or 2) positive assay and negative pathology. The first scenario occurred in only 2 biopsies: $52,129 \mathrm{pg} / \mathrm{mg}$ of tissue (Case 4) and 103,122 pg/mg of tissue (Case 8). The biopsy in Case 8 had evidence of crush artifact but was deemed suspicious for adenoma.

The second scenario was much more common-39 (31\%) of the 127 biopsies exceeded the $200,000 \mathrm{pg} / \mathrm{mg}$ threshold but were not flagged for tumor on pathology. The 39 biopsies were obtained from 10 patients (Table 5). All 10 were eventually cured based on long-term postoperative cortisol levels in the normal range. Three (30\%) of the 10 experienced unexpected postoperative hormonal changes that the physician explicitly attributed to the TSR in the patient record, including secondary hypothyroidism (Case 1), panhypopituitarism (Case 13), and diabetes insipidus (Case 9).

\section{Tumor Characterization and Surgical Evaluation by MRI}

Thirteen of 14 patients had lesions evaluated with MRI at YNHH. The patient in Case 6, the only one who did not have YNHH imaging, was scanned at an outside hospital and the presence of adenoma was confirmed. Two lesions were characterized as macroadenomas and the rest as microadenomas on MRI. Mean adenoma volume was 186.8 $\mathrm{mm}^{3}$, with a mean lesion/total pituitary tissue volume ratio of $21 \%$ (range 5\%-60\%). Complete resection and sufficient residual gland (as a proportion of volume) were confirmed in $11(85 \%)$ and $10(77 \%)$ patients, respectively. Lateralization discordance, defined as a discrepancy in tumor extension along the transverse (left-right) axis between MRI and assay-measured samples, occurred in 3 cases. The tumor in Case 1 was lateralized to the right on imaging, but ACTH values indicated tumor on the left aspect of the gland. The tumor in Case 12 was mostly on the left side based on the assay, whereas preoperative MRI predicted a mostly right-sided tumor. Preoperative MRI detected a left-sided midline lesion in Case 13 but failed to capture a right-sided continuation of the lesion. This abnormality was not visualized on coronal precontrast or static postcontrast T1-weighted images and was only detected on coronal precontrast short tau inversion recovery (STIR) and dynamic postcontrast images, sequences that may not be consistently performed as part of pituitary MRI. For patients in 2 (Cases 1 and 13) of these 3 cases, intraoperative assay values agreed with frozen-section assessments, the current operating room standard, that there was tumor on the patient side that appeared negative for tumor on MRI (Tables 6 and 7, Figs. 3 and 4).

\section{Survival and Hormonal Changes in Study Sample Compared With Historical Controls}

Our own literature review revealed 38 studies providing data on patient follow-up, survival, and long-term remission that were descriptive enough to conduct a direct

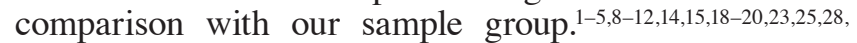
$29,33,34,37,38,40,42,45,47-49,52,54,57,58,61,67,68,70,72$ In aggregating these data, we found a total of 4470 patients who had undergone TSR for Cushing disease and had follow-up from at least 6 months to more than 10 years. The total number of remissions after primary TSR was 3192 and the total number of treatment failures was 1247 , for a mean remission rate of $71.9 \%$. Immediate postoperative treatment failures and disease recurrences were grouped across both controls and 
TABLE 3. Contingency table for intraoperative ACTH assay (criterion of $200,000 \mathrm{pg} / \mathrm{mg}$ ) versus frozen sections

\begin{tabular}{lrrr}
\hline \multicolumn{1}{c}{ Parameter } & Adenomatous Pathology & Nonadenomatous Pathology & Total \\
\hline Positive assay $(\mathrm{ACTH} \geq 200,000 \mathrm{pg} / \mathrm{mg})$ & $38(\mathrm{P}=0.30)$ & $39(\mathrm{P}=0.31)$ & $77(\mathrm{P}=0.61)$ \\
\hline Negative assay $(\mathrm{ACTH}<200,000 \mathrm{pg} / \mathrm{mg})$ & $2(\mathrm{P}=0.02)$ & $48(\mathrm{P}=0.38)$ & $50(\mathrm{P}=0.39)$ \\
\hline Total & $40(\mathrm{P}=0.32)$ & $87(\mathrm{P}=0.69)$ & $127(\mathrm{P}=1.00)$ \\
\hline
\end{tabular}

$P=$ the fraction of total samples.

our study patients. To account for differences in follow-up time, we compared total patient-months in remission and failure between these 4470 patients and our patients and found that the latter experienced a higher level of remission $(85.7 \%$ vs $71.9 \%)$ that was statistically significant $(\mathrm{p}=$ 0.0007, Fisher's exact test, 2-tailed; Table 8).

In a recent meta-analysis of 50 studies spanning 19842011, Roelfsema et al. reported long-term post-TSR outcomes for Cushing patients. ${ }^{53}$ Collectively, the Cushing patients in these studies numbered 5787, and 4207 of them (72.7\%) went into long-term remission over an average follow-up period of $4.91 \pm 0.34$ years. The average remission proportion among all studies was $71.3 \%$ with a range of $41 \%-98 \%{ }^{53}$ These collective and average remission rates were statistically similar to the remission rate we found in our 38-study review (71.9\%; $\mathrm{p}=0.3844$, Fisher's test, 2-tailed). A direct survival comparison with the Roelfsema et al. data could not be conducted, however, given a lack of specific patient information in that meta-analysis.

The overall rate of unexpected hormonal changes (4 [29\%] of 14 patients) attributed to TSR in the record was slightly higher than the rate found in the 5787-patient meta-analysis by Roelfsema et al. (25\% with a range of $0 \%-29 \%$ ). ${ }^{53}$ This mean difference in unexpected hormonal findings was not statistically significant $(\mathrm{p}=0.7596$, Fisher's exact test, 2-tailed). Restricting our sample to only those patients in whom the chemical assay findings differed from the pathology findings, $30 \%$ of patients ( 3 of 10) had unexpected hormonal changes, a rate still higher but not significantly different from the $25 \%$ rate in the Roelfsema et al. meta-analysis ( $\mathrm{p}=1.0000$, Fisher's exact test, 2-tailed). ${ }^{53}$

\section{Discussion}

In this paper we report on the performance of and outcomes associated with a novel intraoperative ACTH sandwich assay on tissue samples obtained in TSRs of ACTH-secreting adenomas in 14 patients with Cushing disease and at least 1 year of institutional follow-up. Pre-

TABLE 4. Evaluative test measures of intraoperative ACTH assay (criterion of $200,000 \mathrm{pg} / \mathrm{mg}$ ) versus frozen sections

\begin{tabular}{lc}
\hline \multicolumn{1}{c}{ Measure } & Result \\
\hline Sensitivity & $95.0 \%$ \\
\hline Specificity & $55.2 \%$ \\
\hline PPV & $49.4 \%$ \\
\hline NPV & $96.0 \%$ \\
\hline Concordance $(\kappa)$ & 0.41 \\
\hline
\end{tabular}

operative and postoperative cortisol levels were used to monitor surgical efficacy, and postoperative unexpected hormonal changes and complications were monitored during follow-up.

The intraoperative TSR protocol was modified with the introduction of the ACTH assay such that if either the assay or the frozen-section pathology returned results positive for tumor, that area of the gland was resected. A comparison of assay results, at different threshold values for the assay, with pathology findings for 127 biopsy samples revealed that the optimal threshold value for discriminating adenomatous and normal tissues is approximately 290,000 $\mathrm{pg} / \mathrm{mg}$ of tissue according to ROC analysis. This threshold jointly maximized the combination of sensitivity (95.0\%), specificity (71.3\%), PPV (60.3\%), and NPV (96.9\%).

These test statistics are comparable to those for frozen sections, the current intraoperative standard for tumor localization. A study of 4100 sections of various brain tumors showed that frozen sections have $95 \%$ diagnostic accuracy as compared to formalin-fixed paraffin-embedded (FFPE) permanent sections, whereas a separate examination of 2156 cases showed that frozen sections were discrepant with FFPE in $2.7 \%$ of cases. ${ }^{60}$ The ACTH-antibody assay has similar sensitivity and a very high NPV, suggesting that the test can be used either in conjunction with or in place of frozen sections. Additionally, the assay can be run using crushed or indeterminate samples that cannot be read by pathology. It is important to clarify that although we have termed frozen sections as the "gold standard" in this paper, we do so from a statistical testing point of view. Based on current suboptimal resection

TABLE 5. Hormonal data for Cushing patients with positive assay and negative pathology

\begin{tabular}{cccccc}
\hline $\begin{array}{c}\text { Case } \\
\text { No. }\end{array}$ & $\begin{array}{c}\text { Notal } \\
\text { Samples }\end{array}$ & $\begin{array}{c}\text { Discordant } \\
\text { Samples }\end{array}$ & $\begin{array}{c}\text { Cure } \\
\text { Status }\end{array}$ & $\begin{array}{c}\text { Postop } \\
\text { Unexpected } \\
\text { Hormonal } \\
\text { Changes? }\end{array}$ & $\begin{array}{c}\text { No. of } \\
\text { Unexpected } \\
\text { Hormonal } \\
\text { Changes }\end{array}$ \\
\hline 1 & 10 & 2 & Yes & Yes & 1 \\
\hline 2 & 5 & 1 & Yes & No & 0 \\
\hline 3 & 11 & 3 & Yes & No & 0 \\
\hline 7 & 9 & 4 & Yes & No & 0 \\
\hline 8 & 13 & 2 & Yes & No & 0 \\
\hline 9 & 14 & 6 & Yes & Yes & 1 \\
\hline 11 & 17 & 4 & Yes & No & 0 \\
\hline 12 & 16 & 5 & Yes & No & 0 \\
\hline 13 & 16 & 7 & Yes & Yes & 1 \\
\hline 14 & 22 & 5 & Yes & No & 0 \\
\hline
\end{tabular}


TABLE 6. Tumor location, size, and discreteness on MRI

\begin{tabular}{|c|c|c|c|c|c|c|c|c|c|}
\hline \multirow[b]{2}{*}{ Case No. } & \multirow[b]{2}{*}{ Type } & \multirow{2}{*}{$\begin{array}{c}\text { Main } \\
\text { Location }\end{array}$} & \multicolumn{4}{|c|}{ Lesion Size } & \multirow{2}{*}{$\begin{array}{c}\text { Total Pituitary } \\
\text { Vol }\left(\mathrm{mm}^{3}\right)\end{array}$} & \multirow{2}{*}{$\begin{array}{l}\text { Lesion/ } \\
\text { Pituitary Ratio }\end{array}$} & \multirow{2}{*}{$\begin{array}{l}\text { Discrete } \\
\text { Tumor }\end{array}$} \\
\hline & & & $\mathrm{TR}(\mathrm{mm})$ & $\mathrm{CC}(\mathrm{mm})$ & $\mathrm{AP}(\mathrm{mm})$ & Vol $\left(\mathrm{mm}^{3}\right)$ & & & \\
\hline 1 & Micro & Rt mid & 8 & 4 & 7 & 117 & 476 & $25 \%$ & Yes \\
\hline 2 & Micro & Ant mid inf & 4 & 4 & 6 & 50 & 1026 & $5 \%$ & Yes \\
\hline 3 & Macro & $\mathrm{Rt}$ & 11 & 7 & 8 & 322 & 1319 & $24 \%$ & Yes \\
\hline 4 & Micro & Rt & 7 & 7 & 6 & 154 & 604 & $25 \%$ & Yes \\
\hline 5 & Micro & Rt lat & 5 & 7 & 5 & 92 & 586 & $16 \%$ & Yes \\
\hline 7 & Micro & Lt pst & 5 & 5 & 4 & 52 & 659 & $8 \%$ & No \\
\hline 8 & Micro & Lt upper & 4 & 4 & 5 & 42 & 806 & $5 \%$ & Yes \\
\hline 9 & Micro & Lt inf mid & 6 & 3 & 4 & 38 & 586 & $6 \%$ & Yes \\
\hline 10 & Macro & $\mathrm{Rt}$ & 14 & 10 & 12 & 879 & 1468 & $60 \%$ & Yes \\
\hline 11 & Micro & $\mathrm{Rt}$ & 10 & 7 & 8 & 293 & 921 & $32 \%$ & Yes \\
\hline 12 & Micro & Rt inf & 5 & 3 & 4 & 31 & 480 & $7 \%$ & Yes \\
\hline 13 & Micro & $\mathrm{Lt}$ & 6 & 6 & 5 & 94 & 443 & $21 \%$ & No \\
\hline 14 & Micro & Lt mid pst & 9 & 7 & 8 & 264 & 612 & $43 \%$ & Yes \\
\hline Average & & & 7.2 & 5.7 & 6.3 & 186.8 & 768.2 & $21 \%$ & NA \\
\hline
\end{tabular}

Ant $=$ anterior $;$ inf $=$ inferior $;$ mid $=$ midline pst $=$ posterior .

rates, interrater reliability concerns, and the presence of artifactual samples that cannot be read on pathology, it is important to recognize that pathology is not perfect. The ideal litmus test for assessing any method of detecting adenomatous tissue, whether assay or frozen section, is to follow long-term outcomes.

Depending on the usage environment of the test, the preferences of the neuropathologist and surgeon, and the available complementary resources for determining tumor margins, thresholds other than $290,000 \mathrm{pg} / \mathrm{mg}$ might be rationally chosen. For instance, a "first-pass" screening test might rely on a low threshold of $100,000 \mathrm{pg} / \mathrm{mg}$ of tissue, which would increase sensitivity to $97.5 \%$ and improve the probability that any sample that might have even a moderate chance of proving adenomatous would be captured. Although the specificity of the test would be very low (28.7\%), the smaller set of prescreened samples could then be examined on pathology to determine which had adenomatous characteristics. Alternatively, a more conservative approach would be to choose a very high threshold of $2,000,000 \mathrm{pg} / \mathrm{mg}$ of tissue, which would reduce sensitivity to $22.5 \%$ but increase specificity to $99.0 \%$. This strategy might instead utilize a pathologist's discriminating eye to determine the tumor potential of most samples, and for only those that are ambiguous on histology would the assay be employed as a confirmatory test.

The reported patient outcomes relied on a relatively low threshold of 200,000 pg/mg of tissue, which corresponded to an aggressive strategy of higher tissue removal at adenomatous borders. Among the 127 biopsy samples, 86 were concordant on both tests and 41 were discordant. Twelve $(86 \%)$ of 14 patients were cured according to long-term cortisol measurements, and 4 (29\%) of the 14 patients experienced unexpected hormonal changes postoperatively. Among only those patients for whom assay results differed with pathology reports, $3(30 \%)$ of 10 patients experienced unexpected hormonal changes postoperatively. Although concordance between ACTH assay and pathology was moderately low in the present study, the cure rate for patients in whom the assay results were discrepant was relatively favorable compared with rates in the literature $(100 \%$ vs an average of $71.9 \%-72.7 \%$, respectively). Furthermore, our long-term remission rate $(85.7 \%)$ under ACTH-assay guidance was statistically higher than that $(71.9 \%)$ among 38 studies without ACTH-assay guidance, whereas the rate of unexpected hormonal changes among our study patients (29\%) did not statistically differ from that in the Roelfsema et al. meta-analysis $(25 \%){ }^{53}$ These preliminary data are promising and suggest that it may be possible to target adenomatous ACTH-secreting lesions with a chemical assay while maintaining a similar rate of postoperative hypopituitarism. This is the most compelling reason to follow ACTH assay results in resection. A failure to resect all of an ACTH-secreting tumor with a first operation relegates that patient to continued hypercortisolism and the ensuing morbidity and mortality. A failure to control this disease with the initial operation means either a second surgical procedure or irradiation of the sella. The former subjects the patient to additional surgical risk, whereas the latter postpones control for several months to a year of continued hypercortisolism. Using a more sensitive ACTH biomarker as the threshold for margins may mean over time that more patients are taking replacement cortisol but better ensures immediate control with a margin that leaves some normal pituitary rather than performing a hypophysectomy when pathological margins are unclear.

Studies show that MRI sensitivity in Cushing disease diagnosis is limited to $50 \%-70 \%,,^{24,71}$ well below that reported for the ACTH assay. Surgical failures still occur in $13 \%-20 \%$ of post-TSR patients in whom preoperative MRI identified an adenoma, suggesting room for improvement, and at least one study has found that long-term postoperative remission and complication rates do not depend on preoperative MRI findings. 1,9,57 This finding could in part be attributable to the small size of most ACTH-secreting adenomas $(<10 \mathrm{~mm}) .{ }^{21}$ Additionally, the relatively 
TABLE 7. Pathological determinations in patients with discrepant MRI and assay findings

\begin{tabular}{|c|c|c|c|c|c|}
\hline Case No. & $\begin{array}{c}\text { MRI } \\
\text { Location }\end{array}$ & Sample Location & $\begin{array}{l}\text { Tissue ACTH } \\
(\mathrm{pg} / \mathrm{mg})\end{array}$ & $\begin{array}{c}\text { Adenoma by Assay } \\
(290,000 \text { pg/mg })\end{array}$ & $\begin{array}{c}\text { Adenoma by } \\
\text { Frozen Section }\end{array}$ \\
\hline \multirow[t]{10}{*}{1} & Rt sided & Mid tumor & 378,125 & Yes & Yes \\
\hline & & Lt normal brain & $2,076,667$ & Yes & Yes \\
\hline & & Rt lat tumor & 208,889 & No & No \\
\hline & & Pst mid inf & 148,876 & No & No \\
\hline & & Lt ant & 67,368 & No & No \\
\hline & & Lt lat \#1 & 56,167 & No & No \\
\hline & & Lt lat \#2 & 236,190 & No & No \\
\hline & & Lt lat \#3 & 79,394 & No & No \\
\hline & & Ant inf mid & 140,000 & No & No \\
\hline & & Lt lat \#4 & 6,063 & No & No \\
\hline \multirow[t]{16}{*}{12} & Rt sided & Rt middle ant & 334,250 & Yes & Yes \\
\hline & & Lt ant middle & $1,047,647$ & Yes & Yes \\
\hline & & Rt middle & 304,743 & Yes & Yes \\
\hline & & Rt ant inf & 225,424 & No & No \\
\hline & & Rt ant superior & 263,604 & No & No \\
\hline & & Middle ant superior & 108,352 & No & No \\
\hline & & Rt ant inf mid & 49,531 & No & Unclear \\
\hline & & Lt middle mid & 900,658 & Yes & No \\
\hline & & Lt lat inf & 222,677 & No & No \\
\hline & & Lt far lat middle & 425,874 & Yes & No \\
\hline & & Middle ant superior & 159,673 & No & No \\
\hline & & Middle mid & 197,701 & No & No \\
\hline & & Lt superior middle & 271,292 & No & No \\
\hline & & Lt superior middle mid & 171,600 & No & No \\
\hline & & Extreme It superior lat & 11,088 & No & No \\
\hline & & Rt extreme superior lat & 17,111 & No & No \\
\hline \multirow[t]{15}{*}{13} & Lt sided & Lt middle & $2,190,187$ & Yes & Yes \\
\hline & & Ant superior middle & 163,656 & No & Unclear \\
\hline & & Lt ant & 417,524 & Yes & Yes \\
\hline & & Rt ant superficial & 323,111 & Yes & Yes \\
\hline & & Rt mid ant inf & 229,323 & No & No \\
\hline & & Rt mid ant superior & 295,333 & Yes & No \\
\hline & & Lt lat middle & 450,328 & Yes & No \\
\hline & & Lt ant superior & $1,037,778$ & Yes & No \\
\hline & & Lt superior middle & 728,889 & Yes & No \\
\hline & & Rt superior ant & 250,750 & No & No \\
\hline & & Rt middle & 99,833 & No & No \\
\hline & & Lt middle pst lat & 448,718 & Yes & No \\
\hline & & Remaining It pituitary & 45,013 & No & No \\
\hline & & Superior mid middle & 110,188 & No & No \\
\hline & & Rt superior middle \#2 & 175,676 & No & No \\
\hline
\end{tabular}

high localization error rate of $23 \%$ found in our data confirms the findings of Hall et al., who noted a $17 \%$ rate of inaccurate neuroimaging localization relative to intraoperative pituitary adenoma localization. ${ }^{24}$ The relatively low sensitivity and high localization error rate of MRI highlights the potential role that assay-guided surgery can play in improving resections.
None of the patients in our study had a complete absence of lesions on preoperative MRI, but this could be due to our small patient sample as well as the high incidence of nondescript pituitary abnormalities $(1.5 \%-31 \%)$, confirmed in the literature. ${ }^{39}$ Nevertheless, data in this study suggest that even among nondiscrete tumors, as exemplified by Cases 7 and 13, an ACTH assay can prove 


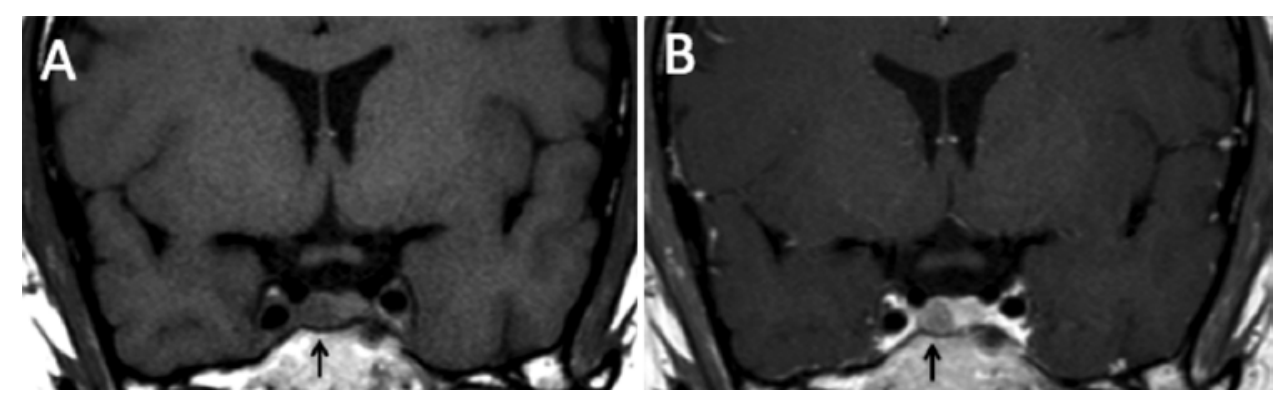

FIG. 3. Case 4. Pathology, ACTH levels, and MRI were well-correlated except for 1 sample of MRI-demonstrated normal pituitary that had low ACTH but mixed adenoma cells with normal pituitary. A: Right-sided hypointense lesion (arrow) on coronal precontrast T1-weighted image. B: Right-sided hypo-enhancing lesion (arrow) on coronal postcontrast T1-weighted image.

useful in distinguishing tumor margins. In the patient in Case 13, the right-sided continuation of the lesion that was confirmed by pathology had not been captured on preoperative MRI. Additionally, the main lesion was picked up only by precontrast STIR and dynamic postcontrast imaging, sequences that are not uniformly obtained preoperatively in assessing the pituitary gland.

These ACTH assay results compare favorably with prior attempts to develop intraoperative assays. ${ }^{16,36,51}$ Lüdecke reported on a now-obsolete antibody-based radioimmunoassay as early as $1989 .{ }^{36}$ In 1994, Raff et al. published a technical demonstration of an immunochemiluminescent assay for ACTH. ${ }^{51}$ Czirják et al. evaluated intraoperative plasma ACTH levels in 7 patients using a rapid immunochemiluminometric method at different stages of surgery. ${ }^{16}$ None of these studies established the sensitivities and specificities of their assays, and all 3 used venous plasma sampling, which cannot differentiate tumor margins in nondiscrete or small tumors and is highly variable because of individual physiological responses to anesthesia. ${ }^{16}$ In contrast, the approach of tissue sampling rather than blood sampling has been used successfully to improve outcomes in the resection of parathyroid tissue in hyperparathyroidism. ${ }^{6,13,41}$ Flitsch et al. did demonstrate that adenomatous lesions secrete much more ACTH than a normal pituitary, but they did not demonstrate the intratumor variability of ACTH or establish an optimal threshold based on sensitivity and specificity. ${ }^{22}$ Furthermore, they used an older method requiring ultrasound homogenization and a fume hood as well as a longer processing time (35 vs 18 minutes). Nevertheless, these investigators found an ACTH maximum of $279,000 \mathrm{pg} / \mathrm{mg}$ of tissue and an ACTH minimum of $345,000 \mathrm{pg} / \mathrm{mg}$ of tissue among adenomas, which corroborates our ROC-derived $290,000 \mathrm{pg} / \mathrm{mg}$ of tissue as a useful discriminatory threshold.

Additional operative time is a potential concern with the adoption of a chemical assay. In practice, whether the assay, frozen-section pathology, or both are used, the time from handing off the sample until report is the same (18 minutes for assay, 15-20 minutes for frozen section). In
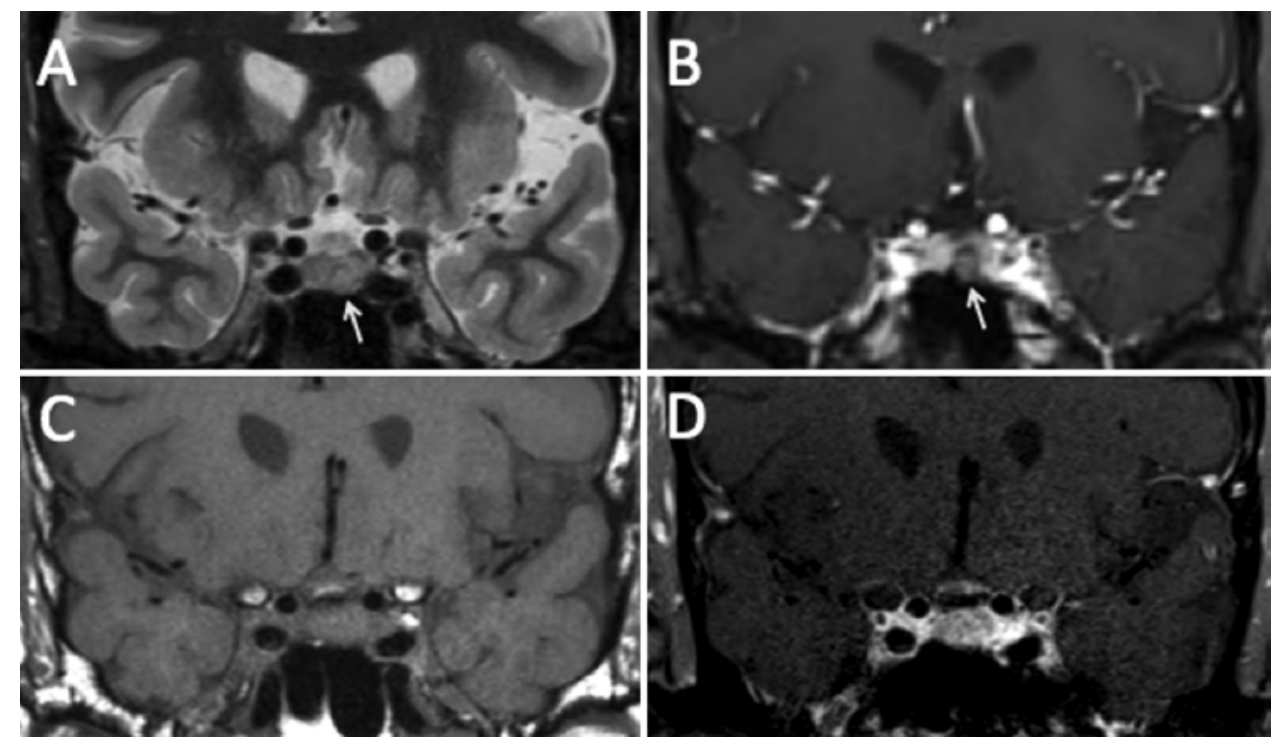

FIG. 4. Case 13. A small tumor was not completely detected on MRI; the right portion of the tumor was not detected. A: Coronal precontrast STIR image shows indistinct middle and left-sided lesion (arrow). B: Dynamic coronal postcontrast image shows a hypo-enhancing abnormality (arrow) in the same location. C: Coronal precontrast T1-weighted image shows no abnormality. D: Static postcontrast image shows no abnormality; the left cavernous sinus appears asymmetrically enlarged, thought to represent a normal variation. 
TABLE 8. Remission and failure in control and sample patient

\begin{tabular}{lrc}
\hline \multicolumn{1}{c}{ Parameter } & Literature Controls & Study Sample \\
\hline Total no. of patients & 4,470 & 14 \\
\hline Total studies & 42 & 1 \\
\hline Patients in remission & 3,192 & 12 \\
\hline Patient-mos in remission & 194,955 & 414 \\
\hline Patients in treatment failure & 1,247 & 2 \\
\hline Patient-mos in failure & 33,538 & 42 \\
\hline
\end{tabular}

fact, frequently at the end of a case, we have all the assay results but can be waiting for final deliberations from pathology.

\section{Study Limitations and Further Research}

Several limitations with the assay, study design, and methods can be identified and should be improved on in succeeding research. The assay itself recognizes both $\mathrm{ACTH}$ and its precursor POMC, which can lead to falsepositive results. This could be one explanation for the low PPV exhibited by the assay, but additional mechanismfocused studies are required. Further research is needed to establish the biological and physical mechanisms by which ACTH levels can differ from pathological examination. Investigations should be conducted into the degree and manner by which the hormone can diffuse intercellularly to otherwise healthy adjacent pituitary cell populations. In terms of study methods, the patient sample size was low but will increase with successive follow-up of additional patients to gather more data on tumor and patient characteristics and to increase statistical power. In the future, particular emphasis will be placed on patients who have had unidentifiable or nondiscrete lesions on preoperative MRI to determine if ACTH guidance can increase tumor detection and complete capture. It will be similarly important to validate the $290,000 \mathrm{pg} / \mathrm{mg}$ threshold for decision making since a lower threshold corresponds to a greater probability of hypopituitarism but also to a greater chance of cure. Finally, the cost-effectiveness of assay use should be evaluated, weighing the benefits of improved outcomes against increased hospital costs and the possibility that more extensive resection could result in a greater likelihood of pituitary hormone deficits.

\section{Conclusions}

This is the first study to report the novel application of this ACTH assay as well as the long-term follow-up of patients whose TSR involved the use of this assay. Twelve $(85.7 \%)$ of 14 patients attained long-term disease remission, as confirmed by UFC in most cases and by plasma cortisol when UFC was not measured. Compared with the average for 4470 historical controls from 38 studies, the cure rate for our study group was statistically significantly higher $(85.7 \%$ vs $71.9 \%)$. However, the rates of long-term unexpected hormonal changes postoperatively were statistically similar between patients in the study group and those in a meta-analysis (29\% and 25\%, respectively). These preliminary findings reflect the promising potential of using an ACTH-guided assay on tissue samples to improve the cure rates of Cushing disease patients undergoing TSR. Further studies with larger sample sizes, further refinement of assay interpretation, and longer-term followups are needed.

\section{Dedication}

We dedicate this article to the memory of our friend, Ed Oldfield. Besides his many scientific and clinical accomplishments, Ed was the consummate surgical endocrinologist and master pituitary tumor surgeon. In particular, his approach to Cushing disease was unsurpassed. We in the field have all learned so much from him and will miss his guidance and his friendship.

\section{References}

1. Acebes JJ, Martino J, Masuet C, Montanya E, Soler J: Early post-operative ACTH and cortisol as predictors of remission in Cushing's disease. Acta Neurochir (Wien) 149:471-479, 2007

2. Alwani RA, de Herder WW, van Aken MO, van den Berge JH, Delwel EJ, Dallenga AH, et al: Biochemical predictors of outcome of pituitary surgery for Cushing's disease. Neuroendocrinology 91:169-178, 2010

3. Atkinson AB, Kennedy A, Wiggam MI, McCance DR, Sheridan B: Long-term remission rates after pituitary surgery for Cushing's disease: the need for long-term surveillance. Clin Endocrinol (Oxf) 63:549-559, 2005

4. Bakiri F, Tatai S, Aouali R, Semrouni M, Derome P, Chitour F, et al: Treatment of Cushing's disease by transsphenoidal, pituitary microsurgery: prognosis factors and long-term follow-up. J Endocrinol Invest 19:572-580, 1996

5. Barbetta L, Dall'Asta C, Tomei G, Locatelli M, Giovanelli M, Ambrosi B: Assessment of cure and recurrence after pituitary surgery for Cushing's disease. Acta Neurochir (Wien) 143:477-482, 2001

6. Barczyński M, Gołkowski F, Nawrot I: The current status of intraoperative iPTH assay in surgery for primary hyperparathyroidism. Gland Surg 4:36-43, 2015

7. Biller BM, Grossman AB, Stewart PM, Melmed S, Bertagna $\mathrm{X}$, Bertherat J, et al: Treatment of adrenocorticotropin-dependent Cushing's syndrome: a consensus statement. J Clin Endocrinol Metab 93:2454-2462, 2008

8. Blevins LS Jr, Christy JH, Khajavi M, Tindall GT: Outcomes of therapy for Cushing's disease due to adrenocorticotropinsecreting pituitary macroadenomas. J Clin Endocrinol Metab 83:63-67, 1998

9. Bochicchio D, Losa M, Buchfelder M: Factors influencing the immediate and late outcome of Cushing's disease treated by transsphenoidal surgery: a retrospective study by the European Cushing's Disease Survey Group. J Clin Endocrinol Metab 80:3114-3120, 1995

10. Boggan JE, Tyrrell JB, Wilson CB: Transsphenoidal microsurgical management of Cushing's disease. Report of 100 cases. J Neurosurg 59:195-200, 1983

11. Buchfelder M, Fahlbusch R, Schott W, Honegger J: Longterm follow-up results in hormonally active pituitary adenomas after primary successful transsphenoidal surgery. Acta Neurochir Suppl (Wien) 53:72-76, 1991

12. Burke CW, Adams CB, Esiri MM, Morris C, Bevan JS: Transsphenoidal surgery for Cushing's disease: does what is removed determine the endocrine outcome? Clin Endocrinol (Oxf) 33:525-537, 1990

13. Calò PG, Pisano G, Loi G, Medas F, Barca L, Atzeni M, et al: Intraoperative parathyroid hormone assay during focused parathyroidectomy: the importance of 20 minutes measurement. BMC Surg 13:36, 2013 
14. Chee GH, Mathias DB, James RA, Kendall-Taylor P: Transsphenoidal pituitary surgery in Cushing's disease: can we predict outcome? Clin Endocrinol (Oxf) 54:617-626, 2001

15. Chen JC, Amar AP, Choi S, Singer P, Couldwell WT, Weiss MH: Transsphenoidal microsurgical treatment of Cushing disease: postoperative assessment of surgical efficacy by application of an overnight low-dose dexamethasone suppression test. J Neurosurg 98:967-973, 2003

16. Czirják S, Bezzegh A, Gál A, Rácz K: Intra- and postoperative plasma ACTH concentrations in patients with Cushing's disease cured by transsphenoidal pituitary surgery. Acta Neurochir (Wien) 144:971-977, 2002

17. de Castro M, Moreira AC: Screening and diagnosis of Cushing's syndrome. Arq Bras Endocrinol Metabol 51:11911198, 2007

18. Dekkers OM, Biermasz NR, Pereira AM, Roelfsema F, van Aken MO, Voormolen JH, et al: Mortality in patients treated for Cushing's disease is increased, compared with patients treated for nonfunctioning pituitary macroadenoma. J Clin Endocrinol Metab 92:976-981, 2007

19. Esposito F, Dusick JR, Cohan P, Moftakhar P, McArthur D, Wang C, et al: Clinical review: Early morning cortisol levels as a predictor of remission after transsphenoidal surgery for Cushing's disease. J Clin Endocrinol Metab 91:7-13, 2006

20. Esposito V, Santoro A, Minniti G, Salvati M, Innocenzi G, Lanzetta G, et al: Transsphenoidal adenomectomy for GH-, PRL- and ACTH-secreting pituitary tumours: outcome analysis in a series of 125 patients. Neurol Sci 25:251-256, 2004

21. Ezzat S, Asa SL, Couldwell WT, Barr CE, Dodge WE, Vance ML, et al: The prevalence of pituitary adenomas: a systematic review. Cancer 101:613-619, 2004

22. Flitsch J, Knappe UJ, Lüdecke DK: Direct intraoperative micromethod for hormone measurements of pituitary tissue in Cushing's disease. Surg Neurol 52:585-591, 1999

23. Flitsch J, Knappe UJ, Lüdecke DK: The use of postoperative ACTH levels as a marker for successful transsphenoidal microsurgery in Cushing's disease. Zentralbl Neurochir 64:6-11, 2003

24. Hall WA, Luciano MG, Doppman JL, Patronas NJ, Oldfield EH: Pituitary magnetic resonance imaging in normal human volunteers: occult adenomas in the general population. Ann Intern Med 120:817-820, 1994

25. Hammer GD, Tyrrell JB, Lamborn KR, Applebury CB, Hannegan ET, Bell S, et al: Transsphenoidal microsurgery for Cushing's disease: initial outcome and long-term results. J Clin Endocrinol Metab 89:6348-6357, 2004

26. Hanley JA, McNeil BJ: The meaning and use of the area under a receiver operating characteristic (ROC) curve. Radiology 143:29-36, 1982

27. Holleman F, Endert E, Prummel MF, van Vessem-Timmermans M, Wiersinga WM, Fliers E: Evaluation of endocrine tests. B: screening for hypercortisolism. Neth J Med 63:348-353, 2005

28. Imaki T, Tsushima T, Hizuka N, Odagiri E, Murata Y, Suda $\mathrm{T}$, et al: Postoperative plasma cortisol levels predict long-term outcome in patients with Cushing's disease and determine which patients should be treated with pituitary irradiation after surgery. Endocr J 48:53-62, 2001

29. Invitti C, Pecori Giraldi F, de Martin M, Cavagnini F: Diagnosis and management of Cushing's syndrome: results of an Italian multicentre study. J Clin Endocrinol Metab 84:440448, 1999

30. Kaye TB, Crapo L: The Cushing syndrome: an update on diagnostic tests. Ann Intern Med 112:434-444, 1990

31. Kelly DF, Barkhoudarian G, Griffiths CF, Karimi K, Cohan P, Ilani N: A Patient's Guide to Endonasal Endoscopic Surgery for Pituitary Adenomas and Related Tumors. Santa Monica: Pacific Pituitary Center at Providence Saint John's Health Center, 2015
32. Knappe UJ, Lüdecke DK: Persistent and recurrent hypercortisolism after transsphenoidal surgery for Cushing's disease. Acta Neurochir Suppl 65:31-34, 1996

33. Kristof RA, Schramm J, Redel L, Neuloh G, Wichers M, Klingmüller D: Endocrinological outcome following first time transsphenoidal surgery for GH-, ACTH-, and PRLsecreting pituitary adenomas. Acta Neurochir (Wien) 144:555-561, 2002

34. Lindholm J, Juul S, Jørgensen JO, Astrup J, Bjerre P, FeldtRasmussen U, et al: Incidence and late prognosis of Cushing's syndrome: a population-based study. J Clin Endocrinol Metab 86:117-123, 2001

35. López J, Barceló B, Lucas T, Salame F, Alameda C, Boronat $\mathrm{M}$, et al: Petrosal sinus sampling for diagnosis of Cushing's disease: evidence of false negative results. Clin Endocrinol (Oxf) 45:147-156, 1996

36. Lüdecke DK: Intraoperative measurement of adrenocorticotropic hormone in peripituitary blood in Cushing's disease. Neurosurgery 24:201-205, 1989

37. Lüdecke DK, Niedworok G: Results of microsurgery in Cushing's disease and effect on hypertension. Cardiology 72 (1 Suppl 1):91-94, 1985

38. Mampalam TJ, Tyrrell JB, Wilson CB: Transsphenoidal microsurgery for Cushing disease. A report of 216 cases. Ann Intern Med 109:487-493, 1988

39. Molitch ME: Pituitary tumours: pituitary incidentalomas. Best Pract Res Clin Endocrinol Metab 23:667-675, 2009

40. Nakane T, Kuwayama A, Watanabe M, Takahashi T, Kato T, Ichihara K, et al: Long term results of transsphenoidal adenomectomy in patients with Cushing's disease. Neurosurgery 21:218-222, 1987

41. Nelson CM, Victor NS: Rapid intraoperative parathyroid hormone assay in the surgical management of hyperparathyroidism. Perm J 11:3-6, 2007

42. Netea-Maier RT, van Lindert EJ, den Heijer M, van der Eerden A, Pieters GF, Sweep CG, et al: Transsphenoidal pituitary surgery via the endoscopic technique: results in 35 consecutive patients with Cushing's disease. Eur J Endocrinol 154:675-684, 2006

43. Oldfield EH, Chrousos GP, Schulte HM, Schaaf M, McKeever PE, Krudy AG, et al: Preoperative lateralization of ACTHsecreting pituitary microadenomas by bilateral and simultaneous inferior petrosal venous sinus sampling. N Engl J Med 312:100-103, 1985

44. Oldfield EH, Doppman JL, Nieman LK, Chrousos GP, Miller DL, Katz DA, et al: Petrosal sinus sampling with and without corticotropin-releasing hormone for the differential diagnosis of Cushing's syndrome. N Engl J Med 325:897-905, 1991

45. Patil CG, Prevedello DM, Lad SP, Vance ML, Thorner MO, Katznelson L, et al: Late recurrences of Cushing's disease after initial successful transsphenoidal surgery. J Clin Endocrinol Metab 93:358-362, 2008

46. Patronas N, Bulakbasi N, Stratakis CA, Lafferty A, Oldfield $\mathrm{EH}$, Doppman J, et al: Spoiled gradient recalled acquisition in the steady state technique is superior to conventional postcontrast spin echo technique for magnetic resonance imaging detection of adrenocorticotropin-secreting pituitary tumors. J Clin Endocrinol Metab 88:1565-1569, 2003

47. Pereira AM, van Aken MO, van Dulken H, Schutte PJ, Biermasz NR, Smit JW, et al: Long-term predictive value of postsurgical cortisol concentrations for cure and risk of recurrence in Cushing's disease. J Clin Endocrinol Metab 88:5858-5864, 2003

48. Pieters GF, Hermus AR, Meijer E, Smals AG, Kloppenborg PW: Predictive factors for initial cure and relapse rate after pituitary surgery for Cushing's disease. J Clin Endocrinol Metab 69:1122-1126, 1989

49. Post KD, Habas JE: Comparison of long term results between prolactin secreting adenomas and ACTH secreting adenomas. Can J Neurol Sci 17:74-77, 1990 
50. Prevedello DM, Pouratian N, Sherman J, Jane JA Jr, Vance ML, Lopes MB, et al: Management of Cushing's disease: outcome in patients with microadenoma detected on pituitary magnetic resonance imaging. J Neurosurg 109:751-759, 2008

51. Raff H, Shaker JL, Nelson DK, Findling JW: Rapid measurement of corticotropin $(\mathrm{ACTH})$ with a modified immunochemiluminescent assay. Clin Chem 40:1344, 1994

52. Robert F, Hardy J: Cushing's disease: a correlation of radiological, surgical and pathological findings with therapeutic results. Pathol Res Pract 187:617-621, 1991

53. Roelfsema F, Biermasz NR, Pereira AM: Clinical factors involved in the recurrence of pituitary adenomas after surgical remission: a structured review and meta-analysis. Pituitary 15:71-83, 2012

54. Rollin G, Ferreira NP, Czepielewski MA: Prospective evaluation of transsphenoidal pituitary surgery in 108 patients with Cushing's disease. Arq Bras Endocrinol Metabol 51:13551361, 2007

55. Rollin GA, Ferreira NP, Junges M, Gross JL, Czepielewski MA: Dynamics of serum cortisol levels after transsphenoidal surgery in a cohort of patients with Cushing's disease. J Clin Endocrinol Metab 89:1131-1139, 2004

56. Saeger W, Ludecke DK, Buchfelder M, Fahlbusch R, Quabbe HJ, Petersenn S: Pathohistological classification of pituitary tumors. Eur J Endocrinol 156:203-216, 2007

57. Salenave S, Gatta B, Pecheur S, San-Galli F, Visot A, Lasjaunias $\mathrm{P}$, et al: Pituitary magnetic resonance imaging findings do not influence surgical outcome in adrenocorticotropin-secreting microadenomas. J Clin Endocrinol Metab 89:33713376, 2004

58. Santoro A, Minniti G, Ruggeri A, Esposito V, Jaffrain-Rea ML, Delfini R: Biochemical remission and recurrence rate of secreting pituitary adenomas after transsphenoidal adenomectomy: long-term endocrinologic follow-up results. Surg Neurol 68:513-518, 2007

59. Semple PL, Laws ER Jr: Complications in a contemporary series of patients who underwent transsphenoidal surgery for Cushing's disease. J Neurosurg 91:175-179, 1999

60. Sharma S, Deb P: Intraoperative neurocytology of primary central nervous system neoplasia: A simplified and practical diagnostic approach. J Cytol 28:147-158, 2011

61. Shimon I, Ram Z, Cohen ZR, Hadani M: Transsphenoidal surgery for Cushing's disease: endocrinological follow-up monitoring of 82 patients. Neurosurgery 51:57-62, 2002

62. Sonino N, Zielezny M, Fava GA, Fallo F, Boscaro M: Risk factors and long-term outcome in pituitary-dependent Cushing's disease. J Clin Endocrinol Metab 81:2647-2652, 1996

63. Swearingen B, Biller BM, Barker FG II, Katznelson L, Grinspoon S, Klibanski A, et al: Long-term mortality after transsphenoidal surgery for Cushing disease. Ann Intern Med 130:821-824, 1999

64. Swearingen B, Katznelson L, Miller K, Grinspoon S, Waltman A, Dorer DJ, et al: Diagnostic errors after inferior petrosal sinus sampling. J Clin Endocrinol Metab 89:3752-3763, 2004
65. Tabarin A, Greselle JF, San-Galli F, Leprat F, Caille JM, Latapie JL, et al: Usefulness of the corticotropin-releasing hormone test during bilateral inferior petrosal sinus sampling for the diagnosis of Cushing's disease. J Clin Endocrinol Metab 73:53-59, 1991

66. Tabarin A, Laurent F, Catargi B, Olivier-Puel F, Lescene R, Berge J, et al: Comparative evaluation of conventional and dynamic magnetic resonance imaging of the pituitary gland for the diagnosis of Cushing's disease. Clin Endocrinol (Oxf) 49:293-300, 1998

67. Tahir AH, Sheeler LR: Recurrent Cushing's disease after transsphenoidal surgery. Arch Intern Med 152:977-981, 1992

68. Tindall GT, Herring CJ, Clark RV, Adams DA, Watts NB: Cushing's disease: results of transsphenoidal microsurgery with emphasis on surgical failures. J Neurosurg 72:363-369, 1990

69. Tritos NA, Biller BMK, Swearingen B: Management of Cushing disease. Nat Rev Endocrinol 7:279-289, 2011

70. Valassi E, Biller BMK, Swearingen B, Pecori Giraldi F, Losa M, Mortini P, et al: Delayed remission after transsphenoidal surgery in patients with Cushing's disease. J Clin Endocrinol Metab 95:601-610, 2010

71. Vidal S, Horvath E, Kovacs K, Scheithauer BW: Tumors of the adenohypophysis, in Lloyd RV (ed): Endocrine Pathology. Differential Diagnosis and Molecular Advances. Totowa, NJ: Humana Press, 2004, pp 61-75

72. Yap LB, Turner HE, Adams CB, Wass JA: Undetectable postoperative cortisol does not always predict long-term remission in Cushing's disease: a single centre audit. Clin Endocrinol (Oxf) 56:25-31, 2002

\section{Disclosures}

The authors report no conflict of interest concerning the materials or methods used in this study or the findings specified in this paper.

\section{Author Contributions}

Conception and design: Erfe, Perry, McClaskey, Inzucchi, James, Eid, Bronen, Mahajan, Spencer. Acquisition of data: all authors. Analysis and interpretation of data: all authors. Drafting the article: Erfe, Inzucchi, Bronen, Mahajan, Spencer. Critically revising the article: Erfe, Perry, Inzucchi, Bronen, Santos, Spencer. Reviewed submitted version of manuscript: Erfe, Perry, Inzucchi, James, Bronen, Santos, Spencer. Approved the final version of the manuscript on behalf of all authors: Erfe. Statistical analysis: Erfe. Administrative/technical/material support: Erfe, Huttner, Santos. Study supervision: Spencer.

\section{Correspondence}

J. Mark Erfe, Yale School of Medicine, 333 Cedar St., New Haven, CT 06510. email: mark.erfe@yale.edu. 